\title{
Histopathological and ultrastructural aspects of mice lungs experimentally infected with dengue virus serotype 2
}

\author{
Débora Ferreira Barreto/ ${ }^{+}$, Christina Maeda Takiya ${ }^{*}$, Hermann Gonçalves Schatzmayr, \\ Rita Maria Ribeiro Nogueira, José da Costa Farias-Filho, Ortrud Monika Barth
}

\begin{abstract}
Departamento de Virologia, Instituto Oswaldo Cruz -Fiocruz, Av. Brasil 4365, 21040-000 Rio de Janeiro, Brasil *Departamento de Histologia e Embriologia, Instituto de Ciências Biomédicas, Universidade Federal do Rio de Janeiro, Rio de Janeiro, RJ, Brasil
\end{abstract}

Histological and ultrastructural alterations in lung tissue of BALB/c mice infected with dengue virus serotype 2 (non-neuroadapted), by intraperitoneal and intravenous routes were analyzed. Lung tissues were processed following the standard techniques for photonic and electron transmission microscopies. Histopathological and ultrastructural studies showed interstitial pneumonia, characterized by the presence of mononuclear cells. In the mouse model, the dengue virus serotype 2 seems to led to a transient inflammatory process without extensive damage to the interalveolar septa, but caused focal alterations of the blood-exchange barrier. Endothelial cells of blood capillaries exhibited phyllopodia suggesting activation by presence of dengue virus. Morphometrical analysis of mast cells showed an expressive increase of the number of these cells in peribronchiolar spaces and adjacent areas to the interalveolar septa. Alveolar macrophages showed particles dengue virus-like inside rough endoplasmic reticulum and Golgi complex, suggesting viral replication. The tissue alterations observed in our experimental model were similar to the observed in human cases of dengue fever and dengue hemorrhagic fever. Our results show that BALB/c mice are permissive host for dengue virus serotype 2 replication and therefore provides an useful model to study of morphological aspects of dengue virus infection.

Key words: dengue-2 virus - BALB/c mice - C6/36 cell line - macrophage - mast cell - ultrastructure

Dengue fever (DF) is an acute infectious disease caused by dengue virus (DENV) (Halstead 1988, Henchal \& Putnak 1990) that belong to the Flavivirus genus of the Flaviviridae family of single-stranded, positive-polarity, enveloped RNAviruses (Chambers et al. 1990). Dengue disease (DEN) has a spectrum of clinical signs and symptoms, ranging from asymptomatic infection to severe and lethal manifestations. The four DENV serotypes (DENV-1, -2, -3, -4) may cause dengue hemorrhagic fever/dengue shock syndrome (DHF/DSS) in humans, with an estimated 100 million new cases of DF and over 250,000 cases of DHF/DSS per year worldwide. The major difficulty in studying DENV infection in humans and for developing a vaccine, is the absence of a suitable animal model which develops a disease with similar aspects of the DHF and DSS (Bhamarapravati 1993). Several studies suggest that mice are a permissive host for DENV (Meiklejhon et al. 1952, Lin et al.1998, Johnson \& Roehrig 1999, An et al. 1999), but in the majority of these models the animals are im-

Financial support: CNPq, Capes, PDTSP

+Corresponding author: barreto@ioc.fiocruz.br

Received 9 October 2006

Accepted 31 January 2007 munocompromised and inoculated by invasive routes with neuroadapted DENV in mice (Table). In the present study we characterized the injuries caused by DENV-2 infection in lung tissue of BALB/c mice using photonic and electron transmission microscopies. Differing from the majority of the mice models, the DENV-2 (nonneuroadapted) were obtained from a patient serum, propagated once in the $\mathrm{C} 6 / 36$ cell line and inoculated by intravenous (i.v.) and intraperitoneal (i.p.) routes.

\section{MATERIALS AND METHODS}

Virus - The virus strain used in our experiments was isolated from a patient serum during an epidemic of DENV-2 in the state of Rio de Janeiro in 1995 and propagated in the Aedes albopictus mosquito cell line (C6/ 36). The serum was tested by the indirect immunofluorescence technique using a type specific DENV-2 monoclonal (3H5, DENV-2) antibody. The virus had not undergone passage in mouse brain. The titer of the virus $\left(10^{6.3}\right.$ TCID $\left._{50} / 0.1 \mathrm{ml}\right)$ was calculated by the method of Reed and Muench (1938).

Cells - The C6/36 monolayers were grown in L-15 medium supplemented with $1 \%$ non-essencial aminoacids, $10 \%$ tryptose phosphate broth, and $10 \%$ fetal bovine serum. The tubes were kept at $28^{\circ} \mathrm{C}$.

Animal - Adult male BALB/c mice, aged 2 months and weighing $25 \mathrm{~g}$, were obtained from the mouse colony maintained in the Department of Virology of the Instituto Oswaldo Cruz-Fiocruz. Mice were i.p. and i.v. inoculated with DENV-2 (dose of 10,000 TCID $50 / 0.2 \mathrm{ml}$ ) and sacrificed after 48, 72 h, 7 and 49 days p.i. Non-infected mice and mice inoculated with L-15 medium were used 
as controls and sacrificed at the same time. The experiments were previously approved by the Animal Experimentation Ethical Committee of the Instituto Oswaldo Cruz-Fiocruz.

Processing of tissues for photonic microscopy analysis - The animals were peritoneally anaesthetized and lung tissue fragments were collected from infected and non-infected mice. Samples were fixed in Millonig's fixative, dehydrated in ethanol, and paraffin-embedded. Sections (5 $\mu \mathrm{m}$ thick) were stained with haematoxilyn and eosin, giemsa, and toluidin Perez blue.

Morphometrical analysis - Numerical density of mast cells was obtained from histological sections of lung fragments from mice $48 \mathrm{~h}$ p.i. stained with toluidin Perez blue. Thirty four images of non-infected animals and 34 images of pulmonar parenchyma of infected animals were obtained and mast cells on each image were quantified. Images were obtained with a 20x objective of a Nikon Eclipse 104 light microscope and digitallized using a Nikon Coolpix 990 camera. Data were submitted to statistical analysis using t-test or Mann Whitney rank sum test considering $\mathrm{p}<0.05$.

Processing of tissues for transmission electron microscope analysis - Lung fragments were collected after 48 and $72 \mathrm{~h}, 7,14$, and 49 days p.i. The infected animals were peritoneally anaesthetized and fixed by perfusion with $4 \%$ paraformaldeyde in sodium phosphate buffer (0.2 M, pH 7.2) by $30 \mathrm{~min}$. In sequence the lungs were carefully collected, the fragments post-fixed by immersion in $2 \%$ glutaraldehyde in sodium cacodylate buffer $(0.2 \mathrm{M}, \mathrm{pH} 7.2)$, followed by $1 \%$ buffered osmium tetroxide, dehydrated in crescent concentrations of acetone, embedded in epoxy resin, and polymerized at $60^{\circ} \mathrm{C}$ during three days. Semithin section of $0.5 \mu \mathrm{m}$ were obtained using a diamond knife (Diatome) adapted to a Reichert-Jung Ultracut E microtome. The sections were stained with methylene blue and azure II solution (Humprey \& Pittman 1974) and observed at a Zeiss Axiophot light microscopy. Ultrathin sections of 50-70 $\mathrm{nm}$ thickness were picked up onto copper grids and stained with uranyl acetate and lead citrate (Reynolds 1963) and observed at a Zeiss EM-900 TEM.

Isolation of DENV-2 in the C6/36 cell line inoculated with the supernatant of lung tissue macerates from infected $B A L B / c$ mice - Lung tissue fragments were washed in phosphate saline buffer (PBS, $\mathrm{pH}$ 7.2) and macerated in Leibovitz medium (L-15), supplemented with antibiotics. The suspension was incubated for $1 \mathrm{~h}$ for antibiotic action, centrifuged at $1400 \mathrm{~g}$ for $5 \mathrm{~min}$ in a refrigerate centrifuge and the supernatant was collected. Cell monolayers were inoculated with $100 \mu \mathrm{l}$ of the cell supernatant and incubated for $1 \mathrm{~h}$ at $28^{\circ} \mathrm{C}$ for virus adsorption. Subsequently monolayers were grown in L-15 medium supplemented with $1 \%$ non-essencial aminoacids, $10 \%$ tryptose phosphate broth, and $10 \%$ fetal bovine serum. The tubes were kept at $28^{\circ} \mathrm{C}$ and observed daily for viral cytopathic effects for 15 days. C6/36 normal cell monolayers were used as negative control, while the positive control consisted of cell monolayers inocu- lated with DENV-2. After the periods of observation, the monolayers were divided into two groups: the first was tested using the indirect immunofluorescence technique with a type-specific monoclonal antibody for dengue serotype $2(3 \mathrm{H} 5, \mathrm{DENV}-2)$ and the second was fixed in $1 \%$ buffered glutaraldehyde, dehydrated, and embedded in epoxy resin as described above.

Broncho-alveolar aspirate - Infected mice were peritoneally anaesthetized and $1 \mathrm{ml}$ of PBS ( $\mathrm{pH} 7.2$ ) was injected by trachea and immediately collected carefully from the mice lungs. The cells resultant of these collect were fixed in $1 \%$ glutaraldehyde in sodium cacodylate buffer $(0.2 \mathrm{M}, \mathrm{pH} 7.2)$, centrifuged at $1500 \mathrm{rpm}$ for three minutes, and processed for ETM observations.

\section{RESULTS}

Clinical signs - Both DENV-2 infected mice groups did not show deaths.

Morphology - Histological (paraffin and semithin sections) and ultrastructural (ultrathin sections) observations of the infected lung tissues demonstrated the presence of an interstitial pneumonia, which was similar for both routes of inoculation.

Intravenous route - At $48 \mathrm{~h}$ p.i. swelling of interalveolar septa, vascular congestion, presence of alveolar macrophages and erythrocytes inside alveolar spaces, and peribronchiolar infiltrate were detected; recruitment of platelets, mononuclear, and polymorphonuclear cells inside blood vessels (Fig. 5) could be also observed. Presence of phyllopodia in endothelial cells (Fig. 6), but without signs of injury or necrosis.

In $72 \mathrm{~h}$ p.i., swollen interalveolar septa (more severe than at $48 \mathrm{~h}$ p.i.), vascular congestion, presence of alveolar macrophages and erythrocytes inside alveolar spaces, small focus of hemorrhagy, oedema and infiltrate in the peribronchiolar space and hyperplasia of the bronchiolar epithelium were observed. The presence of platelets, mononuclear, and polymorphonuclear cells inside blood vessels. Endothelial cells showed a similar profile as observed at $48 \mathrm{~h}$ p.i.

At 7 days p.i., swollen interalveolar septa (more mild than $72 \mathrm{~h}$ p.i.), vascular congestion and presence of alveolar macrophages and erythrocytes inside alveolar spaces were observed as well as the presence of platelets, mononuclear, and polymorphonuclear cells inside blood vessels.

Endothelial cells showed a similar profile as observed at the initial stage of infection (Fig. 7).

In 49 days p.i., few foci of peribronchiolar hemorrhagy and swollen interalveolar septa (Fig. 1), vascular congestion, presence of alveolar macrophages and erythrocytes inside the alveolar spaces and also platelets, mononuclear, and polymorphonuclear cells persisting inside and outside the blood vessels.

Endothelial cells showed a similar profile as observed at the initial stage of infection.

Intraperitoneal route - The alterations observed in lung tissue of mice infected by the i.p. route were mild and focal. From 72 h to 7 days p.i. inflammation was 
TABLE

Experimental mouse models of dengue virus infection

\begin{tabular}{|c|c|c|c|c|c|c|c|}
\hline Animals & Viruses & RI & Histopathology & $\begin{array}{c}\text { Clinical } \\
\text { manifestations }\end{array}$ & $\begin{array}{l}\text { Viruses } \\
\text { isolation }\end{array}$ & $\begin{array}{l}\text { Detection } \\
\text { of antigen }\end{array}$ & References \\
\hline Mice & DENV-2 & IP & $\begin{array}{l}\text { Increase of } \\
\text { vascular } \\
\text { permeability }\end{array}$ & - & - & - & $\begin{array}{l}\text { Chaturvedi et al. } \\
1991\end{array}$ \\
\hline $\begin{array}{l}\text { Suckling } \\
\text { weanling } \\
\text { and adult } \\
\text { mice }\end{array}$ & $\begin{array}{l}\text { DENV-1 } \\
\text { neuro- } \\
\text { adapted }\end{array}$ & $\mathrm{IC}$ & - & Encephalitis & Brain & Neuron & $\begin{array}{l}\text { Cole \& } \\
\text { Wisseman } \\
1969\end{array}$ \\
\hline Nude mice & DENV-1 & $\begin{array}{l}\text { IC } \\
\text { IP }\end{array}$ & - & Encephalitis & $\begin{array}{l}\text { Brain } \\
\text { muscle } \\
\text { lymph nodes } \\
\text { several organs }\end{array}$ & $\begin{array}{l}\text { Neuron } \\
\text { muscle } \\
\text { kupffer cells }\end{array}$ & $\begin{array}{l}\text { Hotta et al. } \\
\text { 1981a } \\
\text { Hotta et al. } \\
1981 b\end{array}$ \\
\hline Adult mice & $\begin{array}{l}\text { DENV-2 } \\
\text { neuro- } \\
\text { adapted }\end{array}$ & $\begin{array}{l}\text { IP } \\
\text { IV }\end{array}$ & - & - & - & $\begin{array}{l}\text { Macrophages } \\
\text { of some } \\
\text { tissues }\end{array}$ & $\begin{array}{l}\text { Boonpucknavig } \\
\text { et al. } 1981\end{array}$ \\
\hline $\begin{array}{l}\text { "scid-hu" } \\
\text { mice }{ }^{a}\end{array}$ & DENV-1 & IP & - & - & $\begin{array}{l}\text { Blood, some } \\
\text { tissues }\end{array}$ & $\begin{array}{l}\text { Some tissues } \\
\text { (one animals) }\end{array}$ & $\begin{array}{l}\text { Marchette et al. } \\
1973\end{array}$ \\
\hline $\begin{array}{l}\text { Several } \\
\text { species of } \\
\text { rodents }\end{array}$ & $\begin{array}{l}\text { DENV-2 } \\
\text { neuro- } \\
\text { adapted }\end{array}$ & IC & - & $\begin{array}{l}\text { Obit, aneroxia, } \\
\text { petechial } \\
\text { gastrointestinal } \\
\text { haemorrhage, } \\
\text { paralysis, } \\
\text { atrophy of } \\
\text { spleen }\end{array}$ & $\begin{array}{l}\text { In C6/36 cells } \\
\text { inoculated of } \\
\text { macerate of } \\
\text { tissues of } \\
\text { infected } \\
\text { animals }\end{array}$ & - & Hotta et al.1996 \\
\hline $\begin{array}{l}\mathrm{AG} 129^{b} \\
\text { mice }\end{array}$ & $\begin{array}{l}\text { DENV-2 } \\
\text { neuro- } \\
\text { adapted }\end{array}$ & IP & - & $\begin{array}{l}\text { Obit, } \\
\text { neurological } \\
\text { abnormality }\end{array}$ & $\begin{array}{l}\text { Serum } \\
\text { spleen }\end{array}$ & - & $\begin{array}{l}\text { Johnson } \\
\text { \& Roehrig } 1999\end{array}$ \\
\hline $\begin{array}{l}\operatorname{SCID}^{c} \\
\text { mice }\end{array}$ & DENV-2 & IP & - & $\begin{array}{l}\text { Anorexia, } \\
\text { asthenia, } \\
\text { paralysis }\end{array}$ & $\begin{array}{l}\text { Liver serum } \\
\text { brain }\end{array}$ & $\begin{array}{l}\text { Hep G2 cells } \\
\text { of the liver, } \\
\text { neuron }\end{array}$ & An et al. 1999 \\
\hline $\begin{array}{l}\text { Several } \\
\text { species of } \\
\text { rodents }\end{array}$ & DENV-2 & IV & - & $\begin{array}{l}\text { Paraplegia, } \\
\text { thrombocytopenia }\end{array}$ & Blood & - & $\begin{array}{l}\text { Huang et al. } \\
2003\end{array}$ \\
\hline $\begin{array}{l}\mathrm{BALB} / \mathrm{c} \\
\text { mice }\end{array}$ & $\begin{array}{l}\text { DENV-2 } \\
\text { neuro- } \\
\text { adapted }\end{array}$ & IP & $\begin{array}{l}\text { Necrosy } \\
\text { haemorrhage of } \\
\text { the spleen }\end{array}$ & $\begin{array}{l}\text { Shock } \\
\text { paralysis } \\
\text { thrombocytopenia }\end{array}$ & Blood & - & $\begin{array}{l}\text { Atrasheuskaya } \\
\text { et al. } 2003\end{array}$ \\
\hline ICR mice & DENV-2/-4 & IC & - & Anaemia & Glial cells & - & $\begin{array}{l}\text { Lucia \& } \\
\text { Kangwanpong } \\
1994\end{array}$ \\
\hline $\begin{array}{l}\text { Newborn } \\
\text { SNC mice }\end{array}$ & $\begin{array}{l}\text { DENV-2 } \\
\text { neuro- } \\
\text { adapted }\end{array}$ & IC & Neuron apoptose & $\begin{array}{l}\text { Fatal } \\
\text { encephalitis }\end{array}$ & Neurons & - & $\begin{array}{l}\text { Deprès et al. } \\
1998\end{array}$ \\
\hline $\begin{array}{l}\text { Immunodefi- } \\
\text { cient mice }\end{array}$ & DENV-2 & IC & - & - & $\begin{array}{l}\text { Brain } \\
\text { spinal cord }\end{array}$ & $\begin{array}{l}\text { Brain } \\
\text { spinal cord }\end{array}$ & $\mathrm{Na}$ et al. 2003 \\
\hline $\begin{array}{l}\mathrm{BALB} / \mathrm{c} \\
\text { mice }^{d}\end{array}$ & DENV-2 & IP & $\begin{array}{l}\text { Focal alterations } \\
\text { in lung, liver, } \\
\text { cerebellum, and } \\
\text { kidney }\end{array}$ & - & $\begin{array}{l}\text { C6/36 cells } \\
\text { inoculate } \\
\text { of macerate } \\
\text { of tissues }\end{array}$ & $\begin{array}{l}\text { C6/36 cells } \\
\text { inoculate } \\
\text { of macerate } \\
\text { of tissues }\end{array}$ & $\begin{array}{l}\text { Barreto et al. } \\
2004\end{array}$ \\
\hline $\begin{array}{l}\text { BALB/c } \\
\text { mice }^{d}\end{array}$ & DENV-2 & IP & $\begin{array}{l}\text { Focal alterations } \\
\text { in liver }\end{array}$ & - & Serum & Liver & $\begin{array}{l}\text { Paes et al. } \\
2005\end{array}$ \\
\hline
\end{tabular}

RI: route of infection; IC: intracranial; IP: intraperitoneal; IV: intravenous; $a$ : immunocompromised mice; $b$ : mice without receptores for IFN $\alpha, \beta$, and $\gamma ; c$ : immunocompromised mice transplanted with human hepatoma cells (Hep G2-permissive cells for infection and replication by DENV); $d$ : experimental mice model developed by our group of research. 

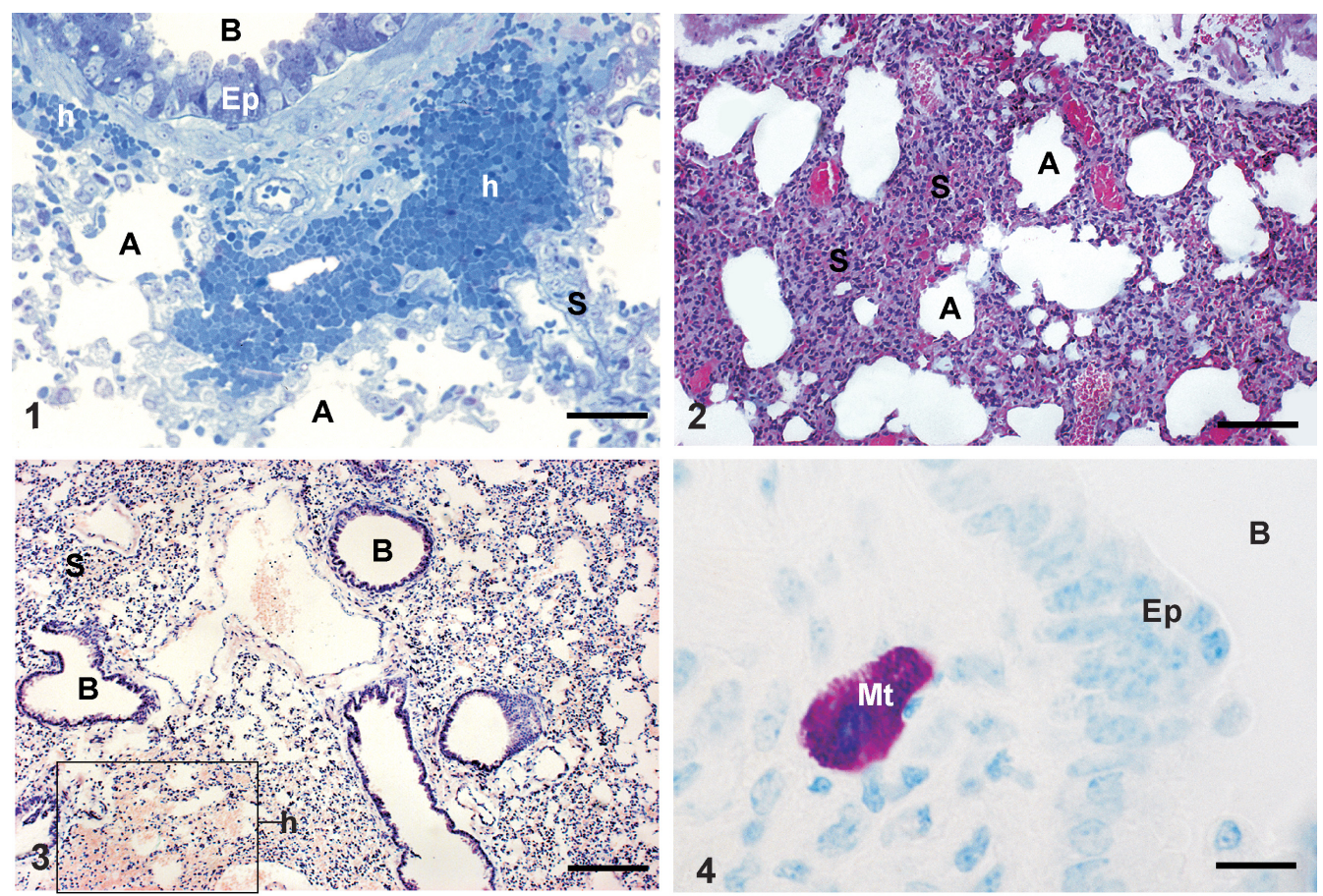

Fig. 1: lung of BALB/c mice 49 days p.i. by i.v. route. Swollen alveolar septa and presence of a hemorrhage focus (h) in peribronchiolar space. Semithin section stained with methylene blue and azure II solution. Bar $=0.025 \mu \mathrm{m}$. Fig. 2: lung of BALB/c mice $72 \mathrm{~h}$ p.i. by i.p. route. Swollen alveolar septa by presence of inflammatory cells and alveolar space diminished can be observed. Histological section stained with haematoxilyn and eosin. Bar $=0.02$ $\mu \mathrm{m}$. Fig. 3: lung of BALB/c mice $72 \mathrm{~h}$ p.i. by i.p. route. Presence of inflammatory cells in alveolar septa and a hemorrhage focus (h) were observed. Histological section stained with giemsa. Bar $=0.001 \mu \mathrm{m}$. Fig. 4: lung of BALB/c mice $72 \mathrm{~h}$ p.i. by i.p. route. Presence of mast cells (Mt) in peribronchiolar space. Histological section stained with toluidin Perez blue. Bar $=0.09 \mu \mathrm{m}$. A: alveolar space; S: alveolar septa, Ep: bronchiolar epithelium; B: bronchiole.
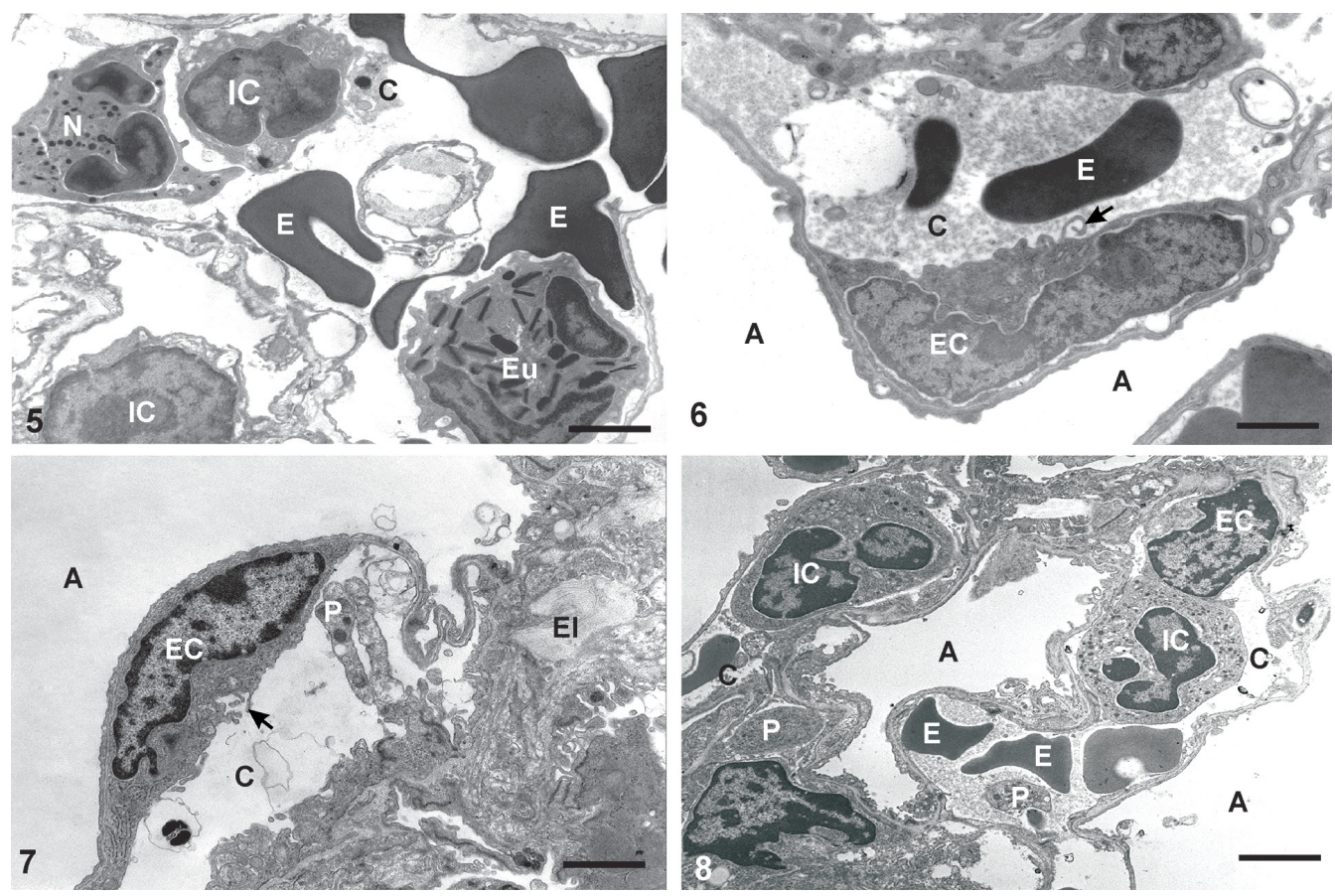

Fig. 5: alveolar septa of lung of BALB/c mice $48 \mathrm{~h}$ p.i. by i.v. route. Presence of mononuclear and polymorphonuclear inflammatory cells (neutrophile and eosinophile) and erythrocytes inside capillaries. Bar $=0.41 \mu \mathrm{m}$. Fig. 6: lung of BALB/c mice $48 \mathrm{~h}$ p.i. by i.v. route. Presence of small phyllopodias (arrow) in cytoplasmatic membrane of endothelial cell and erythrocytes inside capillary. Bar $=0.7 \mu \mathrm{m}$. Fig. 7: lung of BALB/c mice 7 days p.i. by i.v. route. Capillar with platelets inside. Presence of small phyllopodias (arrow) in cytoplasmatic membrane of endothelial cell and production of elastine by fibroblasts in alveolar septa were observed. Bar $=0.27 \mu \mathrm{m}$. Fig. 8: lung of BALB/c mice 49 days p.i. by i.p. route. Note capillaries with inflammatory cells (polymorphonuclear cells), platelets, and erythrocytes inside. Ultra-thin section. Bar $=0.8 \mu \mathrm{m}$. A: alveolar space; C: capillaries; El: elastine; Eu: eosinophile; EC: endothelial cell; E: erythrocytes; IC: inflammatory cells; N: neutrophile; O: oedema; P: platelets. 
also depicted in a peribronchiolar localization (bronchiolitis), admixed with platelets. Recruitment of this type was still evident later, at 14 and 49 days of infection, but decreases progressively, with platelets persisting inside blood vessels (Fig. 8). Polymorphonuclear cells were recruited at a later stage, up to 14 days p.i. Up to $72 \mathrm{~h}$ p.i. swollen of interalveolar septa (Fig. 2), hemorrhage focus (Fig. 3), and hyperplasia of the bronchiolar epithelium were observed. Foci of subepithelial oedema were depicted at 7 days p.i., but rare pneumocytes showed evidence of injury at this stage. They exhibited a dense cytoplasm with swollen mitochondria, whereas in the alveolar septa interstitial fibroblasts containing lipid droplets became evident.

The endothelial cells maintained their structure without signs of reversible injury or necrosis.

Morphometrical analysis - The infected lung tissue showed significant increase in the density of mast cells in $48(\mathrm{p}<0.05)$ and $72 \mathrm{~h}$ p.i. $(\mathrm{p}<0.05)$ by both, the i.p. and the i.v. routes of infection, when compared to controls (Fig. 17). These mast cells were observed in the peribronchiolar space (Fig. 4) and adjacent to the interalveolar septa. The presence of an interstitial oedema was also detected in these area.

Isolation of DENV-2 in the C6/36 cell line inoculated with the supernatant of lung tissue macerates from infected BALB/c mice - In cell cultures of the posi- tive controls (Figs 9, 11) and in monolayer cultures inoculated with the supernatant of the lung tissues (Figs $10,12)$, the DENV-2 antigen and virus particles inside cysterns of the rough endoplasmic reticulum were observed.

Monolayer cells of the negative control showed no morphological alterations, exhibiting neither DENV-2 antigen nor virus particles.

Broncho-alveolar aspirate - All alveolar macrophages, collected 48 and $72 \mathrm{~h}$ p.i. showed pseudopodia (Figs 13, 14). These macrophages were supposely activated by presence of DENV-2.

In $48 \mathrm{~h}$ p.i. (i.p. route) DENV-like particles, were observed inside citoplasmatic vesicles of alveolar macrophages.

In alveolar macrophages of animals $72 \mathrm{~h}$ p.i., particles DENV-like, inside the rough endoplasmic reticulum (i.p. route) (Fig. 15) and Golgi complex (i.v. route) (Fig. 16) were observed.

\section{DISCUSSION}

In this work BALB/c mice infected with DENV-2 (non-neuroadapted) by the intraperitoneal and the intravenous routes, did not show neither clinical signs nor mortality. In experimental studies with defficient mice strains, severe clinical signs and mortality were observed (Raut et al. 1996). In these studies the defficient ani-
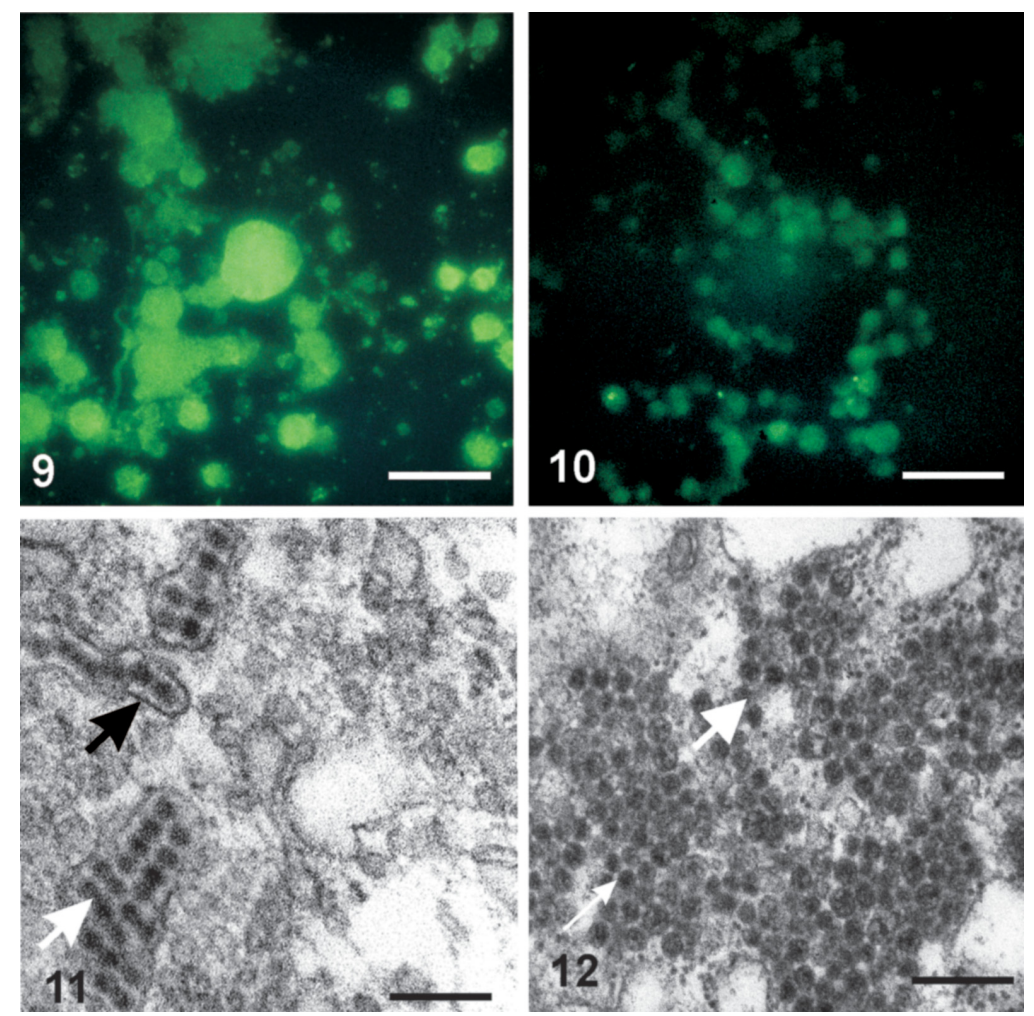

Figs 9-10: detection of DENV-2 antigen in monolayers of C6/36 by immunofluorescence technique. Fig. 9: positive control. Bar = 0.02 $\mu$ m; Fig. 10: monolayer infected with macerate of lung tissue supernatant. Bar $=0.02 \mathrm{~mm}$. Figs $11-12$ : detection of DENV-2 particles in monolayers of C6/36 by electron transmission microscopy technique. Fig. 11: positive control. Bar $=11 \mu \mathrm{m}$; Fig. 12: monolayer infected with macerate of lung tissue supernatant. Bar $=3 \mu \mathrm{m}$. Virus particles (arrow). 

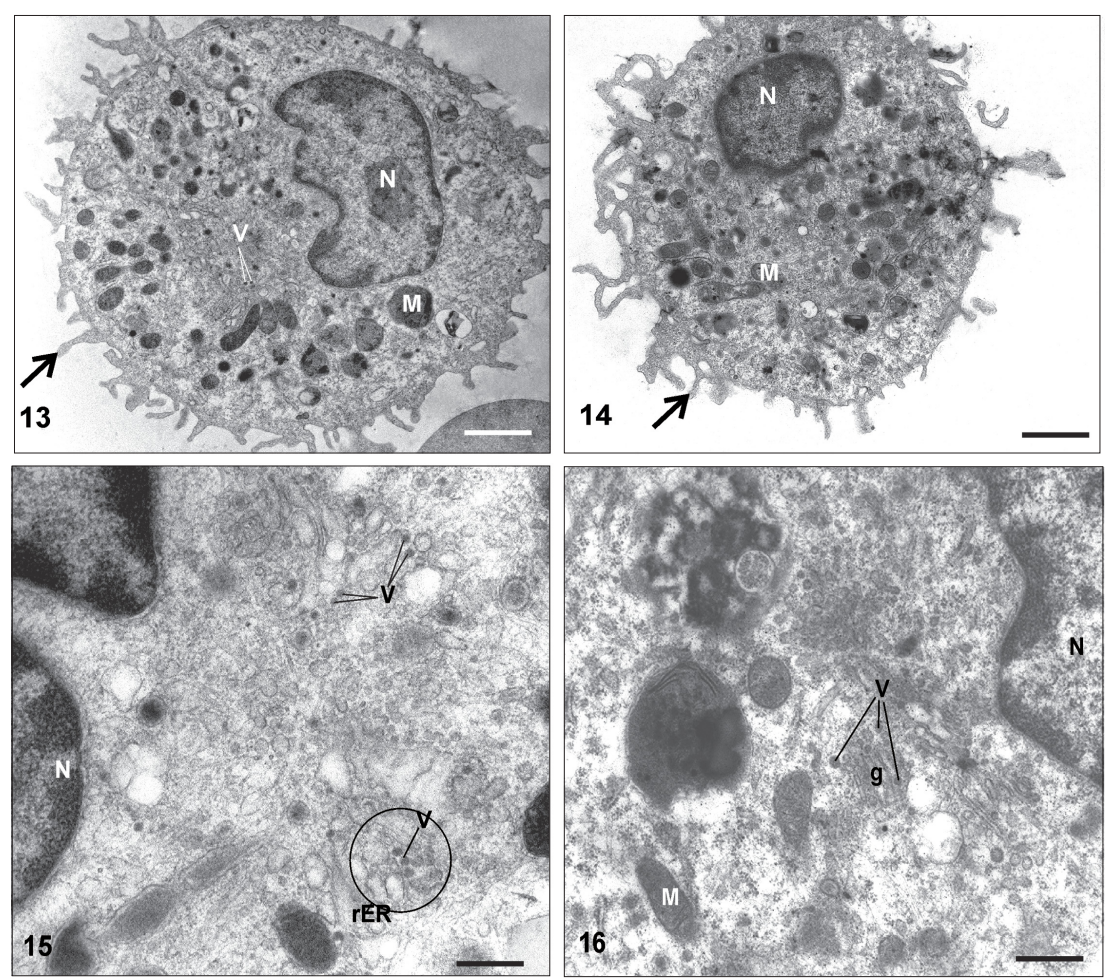

Figs 13-16: alveolar macrophages collected of the BALB/c mice by broncho-alveolar aspirate. Fig. 13: macrophages collected $72 \mathrm{~h}$ p.i. by i.p. route. Note presence of pseudopodia (arrow) and particles DENV-like $(\mathrm{V})$ inside cytoplasmatic vesicles. Bar $=0.7 \mu \mathrm{m}$. Fig. 14 : macrophages collected $72 \mathrm{~h}$ p.i. by i.v. route. Note presence of pseudopodia (arrow). Bar $=0.73 \mu \mathrm{m}$. Fig. 15: macrophages collected $72 \mathrm{~h}$ p.i. by i.p. route. Note presence of particles DENV-like $(V)$ inside rough endoplasmic reticulum. Bar $=2.4 \mu \mathrm{m}$. Fig. 16: macrophages collected $72 \mathrm{~h}$ p.i. by i.p. route. Note presence of particles DENVlike (V) inside Golgi complex. Ultra-thin section. Bar $=2 \mu \mathrm{m}$. M: mitochondria, N: nucleus, rER: rough endoplasmic reticulum.

mals were infected by the intracerebral route with neuroadapted DENV strain. The severity of clinical signs in this work must be correlated with the immunodeficience of these animals and the adaptation of DENV in mice that increase the virulence of this dengue virus strain.

In our studies the histological analysis of lung tissues revealed interstitial pneumonia associated with vascular congestion, rare focal zones of parenquimal haemorrhage, increase of alveolar macrophages number, recruiting of platelets, mononuclear, and polymorphonuclear cells. Histological alterations were still observed in 49 days p.i, being less severe in time. The course of the infection was similar in both routes. The tissular alterations were similar the observed in others animal models (Bhamarapravati 1989, Hotta et al. 1981a, Atrasheukaya et al. 2003). Similar injuries have been observed in necropsies of human pulmonar tissues of DEN fatal cases (Burke et al. 1988, Miagostovich et al. 1997).

In the ultrastructural analysis of alveolar macrophages of infected mice by the intravenous and intraperitoneal routes, the presence of DENV-like particles inside vesicles the rough endoplasmic reticulum and Golgi complex were observed suggesting viral replication. All macrophages presented pseudopodia, probably due to activation by the presence of DENV. DENV antigen and virus particles were detected in monolayers of C6/36 cells inoculated with pulmonar tissue macerate super- natants of infected animals. In immunocompromised mice, the replication of DENV was verified in pulmonar tissue by titulation of cell cultures inoculated with lung tissue macerate (Hotta et al. 1981a). Studies reported that monocytes are more permissive cells for infection by DENV in vitro (Hastead \& O' Rourke 1977). In studies with monocytes gotten of patients with DEN, the DENV were often detected (Scott et al. 1980). Based on these data, several authors suggested that monocytes and macrophages resident in tissues can be target cells predominantly in the infection in vivo by DENV (Rothman \& Ennis 1999). Histochemical studies of human fatal cases of DEN demonstrated that cells of the phagocytic system can be infected by DENV (Miagostovich et al. 1997).

The main characteristic of DHF is the vascular permeability increase resulting in a extensive extravasation of plasma (Innis 1995). Increase of mast cells in the peribronchiolar space and adjacent to the interalveolar septa in lung of mice in our experiments, probably contributes to the permeability changes seen in this organ. Tissue mast cells probably are activated and also involved in DEN injury, since they are usually found in normal and abnormal alveolar wall (Fox et al. 1981). They produce a series of vasoactive mediators, including histamine and histamine-like products. Histamine causes increased capillary permeability by opening the intercellular junctions (Khanna et al. 1990). Russel (1971) sug- 


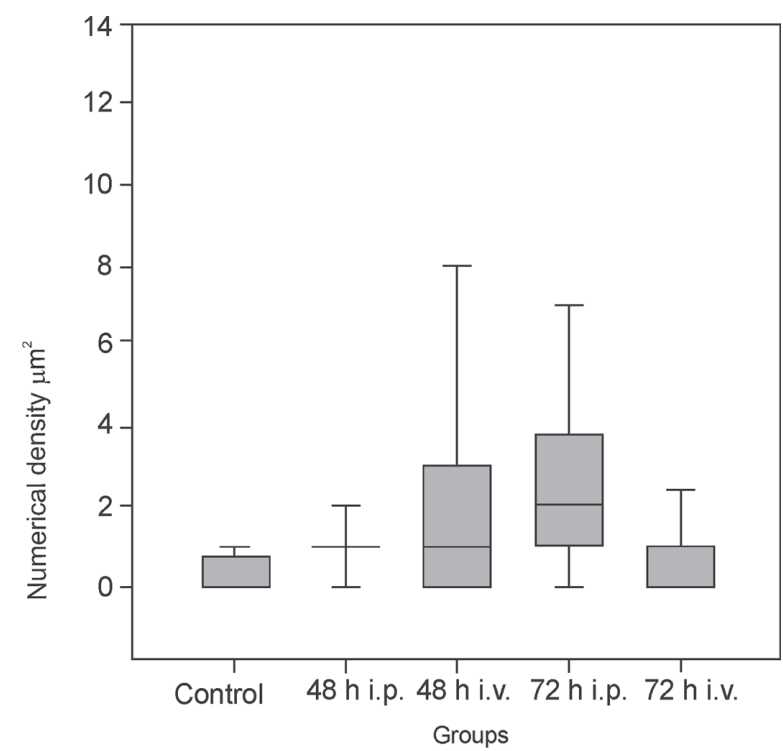

Fig. 17: quantitative analysis of mast cells of BALB/c mice lungs infected with DENV-2. Note increase of the numerical density of mast cells in lungs of infected animals 48 and 72 h post-infection. h: hours, i.p.: intraperitoneal route; i.v: intravenous route.

gests that the histamine can be the mediator of the vascular permeability in DHF and in DSS. In studies with cases of DHF and DSS, increase of levels of histamine in urine was observed (Tuchinda et al. 1977). Studies with human mast cell culture infected with dengue virus suggest a role for these cells in the initiation of chemokinedependent host responses to dengue virus infection (King et al. 2002). Studies with mice inoculated with a cytotoxic factor obtained of spleen of mice infected with DENV showed alterations of the blood-brain barrier, leading to oedema, which was mediated via liberation of histamine (Chaturvedi 1991).

In our mouse model focal alterations of the bloodexchange barrier was verified. The endothelial cells of blood capillaries exhibited phyllopodia but necrosis of this cellular type not was observed. According to Feroze (1997), the presence a of great number of endocytic vacuoles and phyllopodia in endothelial cells can be an indication of activation. It was suggested that endothelial cells can support DENV replication and liberation of several inflammatory mediators including a interleukin 8 (IL-8) and RANTES (Avirutnan et al. 1998, Juffrie et al. 2000). These substances are capable to enlist neutrophiles and to promote vascular permeability increase. In the present work the recruitment of polymorphonuclear cells that occurred in a higher number in a later period of infection was verified. The recruitment of these cells, probablly is due to the release of IL- 8 and RANTES by activated endothelial cells.

Several studies utilizing mice as a experimental model for DENV infection have been carried out. The susceptibility of mice for DENV was demonstrated in several species (Meiklejhon et al. 1952, Lin et al. 1998, Johnson $\&$ Roehrig 1999, An et al. 1999, Atrasheukaya et al. 2003). The susceptibility of BALB/c mice inoculated with neuroadapted DENV by intraperitoneal and intravenous route was demonstrated (Atrasheukaya et al. 2003, Huang et al. 2000). In our studies, DENV were ultrastructurally indentified and immunolocalized in C6/36 cell cultures inoculated with the supernatant of lung tissue macerates of BALB/c mice. Ultrastructural studies showed the presence of DENV-like particles inside vesicles of the rough endoplasmic reticulum and Golgi complex.

This findings are a proof of DENV-2 infection, and confirms that BALB/c mice are susceptible for DENV-2.

\section{ACKNOWLEDGMENTS}

To the staff of the Flavivirus Laboratory of the Departament of Virology for virus isolation and identification, to the Departament of Pathology, and to the Laboratory of Image Processing of the Instituto Oswaldo Cruz; to Ms Vanessa Elen de França Valle for technical assistance.

\section{REFERENCES}

An J, Kimura-Kuroda J, Hirabayashi Y, Yasui K 1999. Development of novel mouse model for dengue virus infection. Virology 263: 70-77.

Atrasheuskaya A, Petzelbauer P, Fredeking TM, Ignatyev G 2003. Anti-TNF antibody treatment reduces mortality in experimental dengue virus infection. FEMS Immunol Med Microbiol 35: 33-42.

Avirutnan P, Malasit P, Seliger B, Bhakdi S, Husman M 1998. Dengue virus infection in human endothelial cells leads to chemokine production, complement activation and apoptosis. J Immunol 161: 6338-6346.

Barreto DF, Takiya CM, Paes MV, Farias-Filho J, Pinhão AT, Alves AM, Costa SM, Barth OM 2004. Histopathological aspects of dengue-2 virus infected mice tissues and complementary virus isolation. J Submicrosc Cytol Pathol 36: 121-30.

Bhamarapravati N 1989. Homostatic defects in dengue hemorrhagic fever. Rev Infect Dis 11(Suppl. 4): S826-829.

Bhamarapravati N 1993. Pathology of dengue haemorrhagic fever. In P Thong-charoen, Monograph on Dengue/Dengue Haemorrhagic Fever, WHO-SEARO, New Delhi 22, p. 72-79.

Boonpucknavig S, Vuttiviroj O, Boonpucknavig V 1981. Infection of young adult mice with dengue virus type 2 . Trans $R$ Soc Trop Med Hyg 75: 647-653.

Burke DS, Nisalak A, Johnson DE, Scott RM 1988. A prospective study of dengue infections in Bangkok. Am J Trop Med Hyg 38: 172-180.

Chambers TJ, Weir RC, Grakoui A, McCourt DW, Bazan JF, Fletterick RJ, Rice CM 1990. Evidence that the N-terminal domain of nonstructural protein NS3 from yellow fever virus is a serine protease responsible for site-specific cleaveages in the viral polyprotein. Proc Natl Acad Sci USA 87: 88988902 .

Chaturvedi UC, Dhawan R, Khanna M, Mathur A 1991. Breakdown of the blood-brain barrier during dengue virus infection of mice. J Gen Virol 72: 859-866.

Cole GA, Wisseman Jr CL 1969. Pathogenesis of type 1 dengue virus infection in suckling weanling and adult mice. The relation of virus replication interferon and antibody formation. Am J Epidemiol 89: 669-680. 
Desprès P, Frenkiel M-P, Ceccaldi P-E, Dos Santos CD, Deubel $\mathrm{V}$ 1998. Apoptosis in the mouse central nervous system in response to infection with mouse-neurovirulent dengue viruses. J Virol 72: 823-829.

Feroze NG 1997. Ultrastructural Pathology on the Cell and Matrix, 4th ed., p. 619-1414.

Fox B, Bull TB, Guz A 1981. Mast cells in the human alveolar wall: an electronmicroscopic study. J Clin Pathol 34: 1333-1342.

Halstead SB 1988. Pathogenesis of dengue: challenges to molecular biology. Science 239(4839): 476-481.

Halstead SB, O'Rourke EJ 1977. Dengue viruses and mononuclear phagocytes. Infection enhacement by non-neutralizing antibody. $J$ Exp Med 146: 201-217.

Henchal FA, Putnak JR 1990. The dengue viruses. Clin Microbiol Rev 3: 376-396.

Hotta H, Murakami I, Miyasaki K, Takeda Y, Shirane H, Hotta S 1981a. Inoculation of dengue virus into nude mice. J Gen Virol 52: 71-76.

Hotta H, Murakami I, Miyasaki K, Takeda Y, Shirane H, Hotta S 1981b. Localization of dengue virus in nude mice. Microbiol Immunol 25: 89-93.

Huang CY, Butrapet S, Tsuchya KR, Bhamarapravati N, Gubler DJ, Kinney RM 2003. Dengue 2 PDK-53 virus as a chimeric carrier for tetravalent dengue vaccien development. $J$ Virol 77: 11436-47.

Huang K-J, Li S-Y L, Chen S-C, Liu H-S, Lin Y-S, Yeh T-M, Liu C-C, Lei H-Y 2000. Manifestation of thrombocytopenia in dengue-2 virus-infected mice. J Gen Virol 81: 2177-2182.

Humprey CD, Pittman EE 1974. A simple methylene blue-azureII basic fuchsin for epoxy-embedded tissue sections. Stain Technol 49: 9.

Innis B 1995. Dengue and dengue hemorrhagic fever. In JS Porterfield, Kass Handbook of Infectious Disease; Exotic Viral Infections, Chapman Hall, London, p. 103-146.

Johnson AJ, Roehrig JT 1999. New mouse model for degue virus vaccine testing. $J$ Virol 73: 783-786.

Juffrie M, Meer DM, Hack CE, Haasnoot K, Sutaryo, Veerman AJ, Thijs LG 2000. Inflammatory mediators in dengue virus infection in children: interleukin-8 and its relationship to neutrophil degranulation. Infect Immun 68: 702-707.

Khanna M, Chaturvedi UC, Sharma MC, Pandey VC, Mathur A 1990. Increased capillary permeability mediated by dengue virus-induced lymphokine. Immunology 69: 449-453.

King CA, Anderson R, Marshalli JS 2002. Dengue virus selec- tively induces human mast cell chemokine production. $J$ Virol 8408-8419.

Lin Y, Liao CL, Chen LK, Yeh CT, Liu CI, Ma SH, Huang YY, Huang YL, Kao CL, King CC 1998. Study of dengue virus infection in SCID mice engrafted with human K562 cells. J Virol 72: 9729-9737.

Lucia HL, Kangwanpong D 1994. Identification of dengue virusinfected cells in paraffin-embedded tissue using in situ polymerase chain reaction and DNA hybridization. $J$ Virol Methods 48: 1-8.

Marchette NJ, Halstead SB, Falkler WA Jr, Stenhouse A, Nash D 1973. Studies on the pathogenesis of dengue infection in monkeys. 3. Sequencial distribuition of the virus in primary and heterologous infection. J Infect Dis 128: 23-30.

Meiklejohn G, England B, Lennette EH 1952. Adaptation of dengue virus strains in unweaned mice. Am J Trop Med Hyg 1: 51-58.

Miagostovich MP, Ramos RG, Nicol AF, Nogueira RMR, CuzziMaya T, Oliveira AV, Marchevsky RS, Mesquita RP, Schatzmayr HG 1997. Retrospective study on dengue fatal cases. Clin Neuropathol 16: 204-208.

Na J, Zhou DS, Kawasaki K, Yasui K 2003. The pathogenesis of spinal cord involvement in dengue virus infection. Virchows Arch 442: 472-481.

Paes MV, Pinhão AT, Barreto DF, Costa SM, Oliveira MP, Nogueira AC, Takiya CM, Farias-Filho JC, Schatzmayr HG, Alves AMB, Barth OM 2005. Liver injury and viremia in mice infected with dengue-2 virus. Virology 338: 236-246.

Raut CG, Deolankar RP, Kolhapure RM, Goverdhan MK 1996. Susceptibility of laboratory-bred rodents to the experimental infection with dengue virus type 2. Acta Virol 40: 143-146.

Reed LJ, Muench H 1938. A simple method of stimating fifty percent endpoints. Am J Trop Med Hyg 27: 493-497.

Reynolds 1963. The use of lead citrate at high $\mathrm{pH}$ as an electron opaque stain in electron microscopy. J Cell Biol 17: 208212.

Rothman AL, Ennis FA 1999. Immunopathogenesis of dengue hemorrhagic fever. Virology 257: 1-6.

Russel PK 1971. Immunopathological mechanism in the dengue shock syndrome. Prog Immunol 1: 831.

Scott RM, Nisalak A, Cheamudon U, Seridhoranakul S, Nimmannitya S 1980. Isolation of dengue viruses from peripheral blood leukocytes of patients with hemorrhagic fever. J Infect Dis 141: 1-6.

Tuchinda M, Dhorreinintra B, Tuchinda P 1977. Histamine content in 24 hours urine in patients with dengue haemorrhagic fever. Southeast Asian J Trop Med Public Health 8: 80. 